\title{
Canine megaesophagus secondary to acetylcholinesterase inhibitors (chumbinho) intoxication: an unusual presentation
}

\author{
[Megaesôfago canino secundário a intoxicação por inibidores da acetilcolinesterase (chumbinho): \\ uma apresentação incomum]
}

\section{"Case Report/Relato de Caso"}

\author{
Juliana Roberts Oaskis ${ }^{1}$, Sofia Munaldi Machado ${ }^{2}$, Jórnie Mantovani Cezana ${ }^{3}$, Wanderson Lopes \\ Andrade $^{4}$, Bruna Batista Palácio ${ }^{5}$, Paulo Sérgio Cruz de Andrade Júnior ${ }^{6}$, Camila Barbosa \\ Amaral $^{7 *}$
}

\begin{abstract}
${ }^{1}$ Instituto Municipal de Vigilância Sanitária, Vigilância de Zoonoses e Inspeção Agropecuária S/IVISA. Especialização em Produção Animal, Higiene e Tecnologia de Produtos de origem Animal, Universidade Federal Fluminense, Niterói, RJ.

${ }^{2}$ Médica-veterinária autônoma, Santa Maria de Jetibá-ES, Brasil.

${ }^{3}$ Médica-veterinária autônoma, Vitória-ES, Brasil.

${ }^{4}$ Programa de Pós-Graduação Mestrado em Ciências Veterinárias - Universidade Federal do Espírito Santo, Alegre, ES. Especialização em Produção Animal, Higiene e Tecnologia de Produtos de origem Animal, Universidade Federal Fluminense, Niterói, RJ.

${ }^{2}$ Médica-veterinária autônoma, Vitória-ES, Brasil

${ }^{6}$ Instituto Federal do Espírito Santo, Campus Alegre, Rive, Alegre-ES, Brasil.

${ }^{7}$ Departamento de Medicina Veterinária, Centro de Ciências Agrárias e Engenharias, Universidade Federal do Espírito Santo, Alegre - ES, Brasil. Programa de Pós-Graduação em Clínica e Reprodução Animal, Faculdade de Veterinária, Universidade Federal Fluminense, Niterói - RJ.

*Autor para correspondência/Corresponding author: E-mail: camilaosso@gmail.com
\end{abstract}

\begin{abstract}
Megaesophagus is a disease characterized by generalized esophageal dilatation, resulting from reduced or absent esophageal motility. It can be congenital or acquired and some common causes are persistent right aortic arch and myasthenia gravis. It can also be secondary to a variety of diseases, including intoxications. Although organophosphate poisoning is cited as a possible cause of megaesophagus, literature reports in dogs are rarely described. Such condition should have its importance emphasized, since poisoning by pesticides are relatively common in domestic animals and humans, whether accidently or intentionally. This study aimed to report the case of a dog which survived an episode of intentional pesticide poisoning and developed megaesophagus afterwards. The dog presented clinical signs of regurgitation around two weeks after surviving an intoxication episode. The diagnosis was based on clinical features and contrasted radiographic imaging (esophagography) using barium sulfate, which confirmed the diagnosis. Since no megaesophagus-related clinical signs were present before the intoxication episode, its relation to organicphosphorus induced delayed neuropathy (OPIDN) was presumed. Unfortunately, the owner delayed seeking veterinary assistance and the dog's condition deteriorated, despite therapeutic efforts, leading to death. Necropsy was not authorized. This case highlights the importance of monitoring canine patients which survived an intoxication episode and also draws attention to the illegal use of organophosphate compounds in Brazil and its impact in humans, domestic animals and wildlife.
\end{abstract}

Keywords: carbamate pesticides; dilation; dogs; esophagus; toxicity.

\section{Resumo}

O megaesôfago é uma doença caracterizada por dilatação esofágica generalizada, resultante da redução ou ausência de motilidade. Pode ser congênito ou adquirido e algumas das causas mais comuns são a persistência do arco aórtico direito e a miastenia gravis. Pode ainda ser secundário a diversas doenças, incluindo intoxicações. Apesar de o envenenamento por organofosforados ser citado como possível causa de 
megaesôfago, relatos em cães são raramente descritos. Tal condição deve ter sua importância enfatizada, já que o envenenamento por pesticidas é relativamente comum em animais domésticos e humanos, acidental ou intencionalmente. Este estudo visa relatar o caso de um cão que sobreviveu a um episódio de envenenamento intencional por pesticida e posteriormente desenvolveu quadro de megaesôfago. $\mathrm{O}$ cão apresentou sinais clínicos de regurgitação cerca de duas semanas após sobreviver a uma intoxicação por "chumbinho". O diagnóstico foi baseado nas características clínicas e no exame radiográfico contrastado (esofagografia) utilizando sulfato de bário, que confirmou a suspeita. Já que nenhum sinal clínico de megaesôfago havia sido observado anteriormente a intoxicação, presumiu-se sua relação com a neuropatia tardia induzida por organofosfato (NTIOF). Infelizmente, o tutor demorou a buscar assistência veterinária e a condição do cão deteriorou, levando-o ao óbito, independente dos esforços terapêuticos. O exame necroscópico não foi permitido. Este caso ressalta a importância do monitoramento de pacientes caninos sobreviventes a um episódio de intoxicação e chama a atenção para o uso ilegal de organofosforados no Brasil e seus impactos em humanos, animais domésticos e selvagens.

Palavras-chaves: pesticidas carbamatos; dilatação; cães, esôfago; toxicidade.

\section{Introduction}

Megaesophagus is a well-established disease defined by a generalized esophageal dilatation, resulting in reduced or absent esophageal motility. Most frequently, clinical signs are regurgitation, weight loss, cachexia, dysphagia, and eventually cough and pneumonia, secondary to alimentary content aspiration (Mace et al., 2013; Manning et al., 2016; Kanemoto et al., 2017).

It is classified as congenital, idiopathic or secondarily acquired. Megaesophagus secondarily acquired results from numerous primary causes; most of them lead to motor alterations in esophagus or cardia, as cited: myasthenia gravis and lupus erythematosus, as well as diseases that cause direct damage leading to a diffuse neuromuscular dysfunction of the esophageal musculature, such as obstructive foreign bodies, neoplasias and stenosis. Intoxication reports causing megaesophagus are rare, excepting a case report secondary to tiger snake (Notechis scutatus) envenomation (Hopper et al., 2001) though pesticides and herbicides are cited as a possible cause of megaesophagus in veterinary literature (Mace et al., 2013).

Megaesophagus diagnosis is based on clinical signs and demands radiographic confirmation. Gas-dilated esophagus, food retainment, heart and trachea ventral displacement, besides aspiration pneumonia is often seen. An esophagography using barium sulphate is required for confirmation, as a gold standard method for megaesophagus diagnosis. Images outline the dilated esophageal portion and also mechanical obstruction (Mace et al., 2013).
Caution must be taken with contrast aspiration by the patient during the exam. Radiographs can sometimes aid revealing underlying causes such as vascular ring anomalies (Biasato et al., 2017) while fluoroscopy and esophagoscopy are rarely relevant (Mace et al., 2013).

Clinical treatment is supportive and symptomatic. It aims to restore and maintain nutritional equilibrium of the patient while preventing aspirative pneumonia and esophagitis, what can be achieved with high-calorie meals with the dog in cranially elevated position (Mace et al., 2013). In some cases, when a specific cause is identified, an efficient treatment can lead to reversion of megaesophagus (Fracassi and Tamborini, 2011; Mace et al., 2013).

Prognosis varies from guarded to poor, depending on the cause of megaesophagus (Fracassi and Tamborini, 2011; Mace et al., 2013; Biasato et al., 2017). However, early diagnosis and appropriate supportive therapy can result in good and long-term quality of life (Mace et al., 2013).

Numerous cases of pesticides intoxication are attended annually at veterinary and medical clinics all over the world, whether accidental or intentional. It is unquestionably considered a public health problem. Many studies report forensic investigation of domestic and wild animal intentional death by pesticides, with carbamate pesticides aldicarb and carbofuran figuring among the most implicated compounds (Tennakoon et al., 2009; Arnot et al., 2011; de Siqueira et al., 2015; Ruiz-Suárez et al., 2015; Caloni et al., 2016).

"Chumbinho" is the Brazilian popular name of a rodenticide consisting of a mixture of aldicarb 
and carbofuran among other substances, banned by Brazilian Health Surveillance Agency (ANVISA) since October 2012, which unfortunately still figures in black market and is implicated in killing animals and people as a suicide or homicide method in many other countries (de Siqueira et al., 2015).

Animal cruelty is an environmental crime in Brazil but it has been looking forward to consider it also under civil and criminal instances what could increase penalty (de Siqueira et al., 2015). Other countries, such as Spain, highlight the impact of pesticide poisoning in wild animals under biodiversity conservation view (RuizSuárez et al., 2015).

Intentional poisoning is suspected especially when food baits with blackish granules or powder is found in gastric contents of the dead animal or near its body/carcass (Tennakoon et al., 2009; Arnot et al., 2011; de Siqueira et al., 2015; Ruiz-Suárez et al., 2015; Caloni et al., 2016). Many police report in Brazil imply neighbor threats and/or family brawl (de Siqueira et al., 2015). In countryside, abandoned animals, mostly dogs and cats, are common and "chumbinho" is frequently used intentionally by the local population as a "control measure". This behavior clearly demonstrates the common sense of impunity since efficient measures to punish this crime and restrain illegal commerce are absent in development countries (de Siqueira et al., 2015; Ruiz-Suárez et al., 2015). In some countries of European Union, due to restrictive measures, poisoning by these pesticides is decreasing (Caloni et al., 2016).

Intoxicated animals present salivation, vomiting, diarrhea, miosis, bradichardia, bronchial spasms with fluid accumulation, muscle tremor, ataxia, loss of contractile respiratory muscles capacity, cyanosis, depression and death by asphyxia due to muscarinic and nicotinic receptors overstimulation. It requires immediate veterinary intervention but since in most cases lethal doses are ingested, only a few survive (de Siqueira et al., 2015; Caloni et al., 2016).

In humans, an intermediate syndrome (IS) and an organophosphate-induced delayed neuropathy (OPIDN) are well known with many cases described attributed to organophosphate ingestion although there are some cases attributed to carbamates (Lotti and Moretto, 2006; Jokanovic et al., 2011; King and Aaron, 2015). In veterinary medicine, very little is known about it:
OPIDN is described in two cats and recently, a suspected intermediate syndrome (IS) was described in a dog (Tinson et al., 2017).

Considering this scenario, reports of carbamate intoxication sequels are rarely found in veterinary literature. The present article aims to describe the exceptional case of a patient attended at the University Veterinary Hospital which, having survived a "chumbinho" intoxication episode, presented clinical signs compatible with megaesophagus secondary acquired a few days afterwards, confirmed by esophagography.

\section{Description of the Case}

A two-year-old male dog, of no specific breed was attended at a Federal University Veterinary Hospital presenting recurrent vomiting episodes and progressive weight loss. According to the owner, two months before, the dog suffered a "chumbinho" intoxication, developing clinical signals like hypersalivation, emesis, miosis and muscle tremors. At the occasion, the owner found a bait made of raw meat with blackish powder compatible with "chumbinho" nearby. Emergency treatment was properly applied in time and the dog survived but since then it manifested weight loss and unmanageable vomiting. During anamnesis, the owner reported that vomiting was soon after eating and pieces of undigested food were present. Due to this, regurgitation was considered, leading to megaesophagus suspicion. At clinical exam was noticed: cachexia (Figure 1), sialorrhea, grade III/IV systolic cardiac murmur, dry seborrhea and some pilous rarefaction areas along the body.

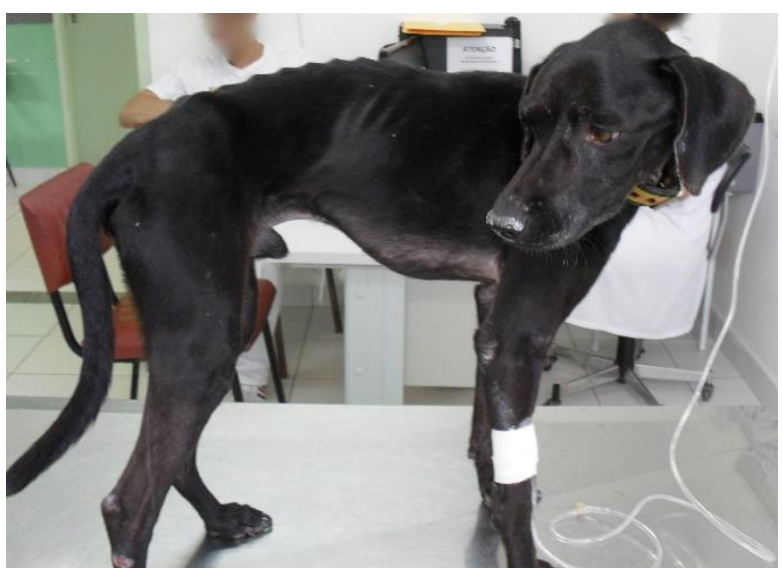

Figure 1. Male dog, of non-specific breed showing severe cachexia during attendance at Veterinary Hospital. Spinous process and ribs easily observed. 
Hematologic exams showed only mild anemia. During attendance, food and water were offered. The dog regurgitated, even showing appetite, characterizing dysphagia and confirming regurgitation. To diagnostic confirmation, at first a lateral thoracic radiography was performed followed by contrasted exam, esophagography, using $100 \%$ barium sulphate, $5 \mathrm{ml} / \mathrm{kg}$ oral dose, totalizing $35 \mathrm{ml}$.

Initial incidences showed ventralization of thoracic tracheal silhouette and marked radioluscency on cervical and thoracic esophagus topography (Figure 2).

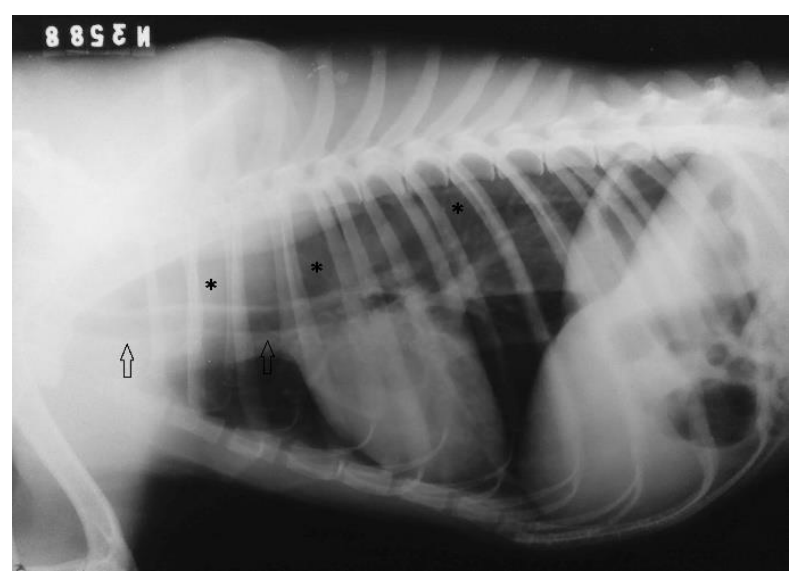

Figure 2. Thoracic radiography, lateral projection of the affected dog: notice tracheal ventralization (arrows) and marked radioluscency at thoracic esophageal topography $(*)$.

Esophageal dilatation was noticed at esophagography initializing at sixth cervical vertebra extending till sixth thoracic vertebra, confirming megaesophagus suspicion (Figure 3 and 4).

After diagnostic conclusion, internment was proposed based on animal condition but due to financial limitation, the owner declined it. Domestic palliative treatment was established based on feeding management: hypercaloric diet, in small portions, keeping the patient in stand up positioning. Ranitidine was prescribed at 0,5 $\mathrm{mg} / \mathrm{kg}$ IV twice daily. The owner was advised to bring the dog back to day-hospital care if feeding management were not possible.

Even with proper domestic treatment, the patient deceased a week later and necropsy was not allowed.

\section{Discussion}

Intoxication in companion animals is whether accidental or intentionally. Accidents come to happen as owner's imprudence who seeks alternatives to eradicate noxious weeds, even conscious of its danger and illegality (Caloni et al., 2016). However, in several Brazilian cities, such as those of countryside, intentional poisoning of errant dogs and cats is a frequent attitude, with high numbers of intoxicated dogs and cats, and registration of more than fifteen dogs intoxicated in only two weeks, alerting veterinary medicine academic institutions with notification by the local media. Similarly to what happens in Canary Island, Spain, and South Africa, despite knowledge of violating actual legislation and under detention and fee penalties, a common sense of impunity is noticed in these cases (Arnot et al., 2011; Ruiz-Suárez et al., 2015).

Our patient was intentionally poisoned since the owner reported having found the meat bait with blackish granules, similar to other cases (Tennakoon et al., 2009; Arnot et al., 2011; de Siqueira et al., 2015; Ruiz-Suárez et al., 2015; Caloni et al., 2016). This information was also confirmed by the veterinary physician. Probably, the amount of toxic substance ingested was below lethal dose and veterinary intervention was effective, guaranteeing survival.

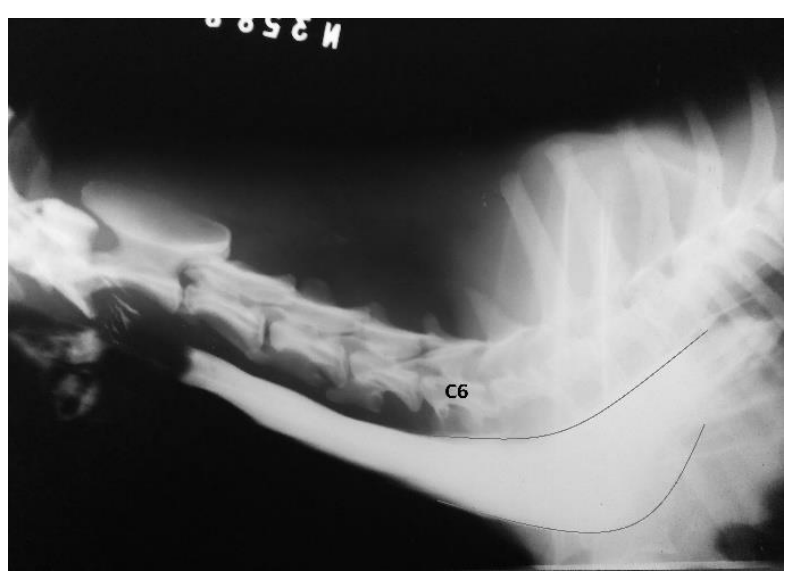

Figure 3. Cervical radiography, lateral projection of the affected dog, esophagography with barium sulphate: esophageal dilation starting at C6 level and continuing within the thorax (outlined).

Post-intoxication megaesophagus development reports are rare in companion animals, with scarce citation of organophosphates (Mace et al., 2013) and only one case by ophidian accident (Hopper et al., 2001). All of them reported that dogs had no signs of megaesophagus before intoxication, similarly to the dog in our case. The mechanism by which organophosphates cause megaesophagus is unknown. A late-phase 
peripheral neurological dysfunction known in humans as organic-phosphorus induced delayed neuropathy (OPIDN) is described to occur seven to twenty one days after acute intoxication or even months and can be permanent. It involves inhibition of a neuropathy target esterase, causing a "dying back" neuronopathy, which leads to weakness and muscular flaccidity starting in pelvic limbs. Carbamates were believed incapable of causing this syndrome but nowadays it is proven so (Lotti and Moretto, 2006; Jokanovic et al., 2011; King and Aaron, 2015).

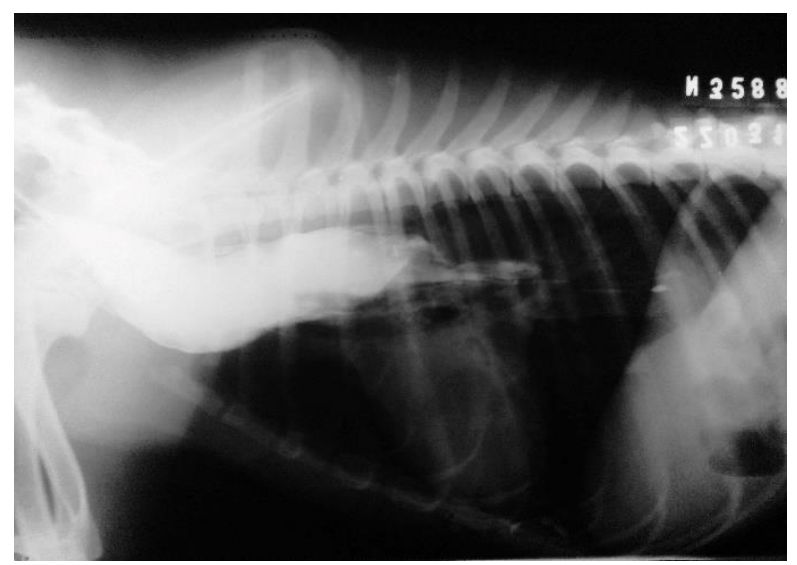

Figure 4. Thoracic radiography, lateral projection of the affected dog, esophagography with barium sulphate: cranial portion of thoracic esophageal segment is dilated and filled with positive contrast.

"Chumbinho" is known to be a mixture of substances, including organophosphates, carbamates or both in most of the cases. As such, and without toxicological evaluation of the bait, it is not possible to determine the etiology agent of our patient previous intoxication. However, the following facts must be considered: both compounds are capable of causing OPIDN, the dog showed no clinical signs of megaesophagus before intoxication episode and megaesophagus clinical signs were observed between ten to fourteen days after intoxication according to the owner information. So, it is possible that our patient, after surviving the pesticide intoxication episode, presented some degree of neuromuscular impairment related to OPIDN syndrome, developed focal muscular weakness, presenting megaesophagus and its clinical signs. The exact mechanisms of this sequel remain to be elucidated.

The signs presented by this patient included regurgitation, dysphagia, dehydration and cachexia, in agreement with literature (Hopper et al., 2001; Fracassi and Tamborini, 2011; Mace et al., 2013; Manning et al., 2016; Biasato et al., 2017; Kanemoto et al., 2017). Differing from megaesophagus development after snake bite, in which clinical signs arise within 48 hours to a week later, in this pesticide intoxication, the outbreak of the symptoms was noticed two weeks after poisoning episode, although, more than a month had passed before veterinary assistance was sought, as evidenced by cachexia of the dog. This time line can help supporting the theory of megaesophagus development due to late-phase peripheral neuropathy and that it was permanent.

Esophagography is adamant to diagnose megaesophagus, its possible underlying cause and aspirative pneumonia (Hopper et al., 2001; Mace et al., 2013; Biasato et al., 2017). In our patient, the exam was performed without intercurrences, contrary to what is highlighted by some authors regarding contrast aspiration (Mace et al., 2013). A marked esophageal dilatation was observed, initializing at cervical final portion and extending till heart base but no vascular ring anomaly was evident, as usually occurs in such cases (Mace et al., 2013; Biasato et al., 2017). The hypothesis of a vascular ring anomaly as the megaesophagus cause was rejected considering the patient age and the fact it had never presented these clinical signals before. No pulmonary alteration suggestive of aspirative pneumonia was observed, a positive aspect in this patient case.

Therapeutic management aimed to recover nutritional balance, rise body score and reduce clinical signs, rendering better welfare during meals, diminishing regurgitations episodes and the possibility of aspiration pneumonia as a complicating factor as recommended (Hopper et al., 2001; Fracassi and Tamborini, 2011; Mace et al., 2013; Manning et al., 2016; Biasato et al., 2017; Kanemoto et al., 2017). Considering the patient's condition, an intensive medical care with feeding tube placement was indicated but not financially feasible by the owner who preferred home care modality. Despite this effort, probably due to advanced cachexia and high debility, the patient deceased little time afterwards and necropsy exam was not performed. Poor prognosis with ultimate death is often seen in patients with megaesophagus and extreme malnutrition and aspiration pneumonia (Mace et al., 2013; Manning et al., 2016; Kanemoto et al., 2017). Although our patient showed no radiographic signs of aspiration pneumonia, its 
cachexia represented an advanced and severe state with possibly metabolic alterations incompatible with life.

\section{Conclusion}

Authorities' attention must be driven to the use of prohibited toxic compounds and inspection of their selling, to avoid reports such as the one presented here besides all deaths, so frequent in companion animals veterinary clinics, whether criminal or accidental.

Animals who survive intoxication episodes should be monitored and evaluated in the subsequent weeks and months regarding its consequences. Therefore, veterinarians will be able to comprehend, diagnose and treat these syndromes. Intoxication-derived megaesophagus may be rare but requires companion animal's clinician attention. Megaesophagus is a disease of relatively simple treatment; however, patient body condition may deteriorate considerably to lifethreatening point without management, as observed in this case. Also, despite recent advances in diagnostic imaging field, esophagography still is a fundamental tool to megaesophagus diagnose and its concomitant alterations such as aspirative pneumonia.

\section{Conflict of Interest}

The authors declare having no conflict of interest.

\section{Acknowledgements}

To Ms. Renata Rodrigues Ferreira, for reviewing the article and to Mr. Bernardo Barbosa Amaral for figure management.

\section{References}

Arnot, L.F.; Veale, D.J.H.; Steyl, J.C.A.; Myburgh, J.G. Treatment rationale for dogs poisoned with aldicarb (carbamate pesticide). Journal of the South African Veterinary Association, 82(4): 232-238, 2011.

Biasato, I.; Lanteri, G.; Guarda, F.; Capucchio, M.T.; Marino, F.; Briguglio, G.; Macri, F. Unusual combination of multiple vascular anomalies in a German Shepherd puppy with megaoesophagus. Anatomia, Histologia, Embryologia, 46(2): 216-219, 2017.

Caloni, F.; Cortinovis, C.; Rivolta, M.; Davanzo, F. Suspected poisoning of domestic animals by pesticides. The Science of the Total Environment, 539: 331-336, 2016. de Siqueira, A.; Salvagni, F.A.; Yoshida, A.S.; Gonçalves-Junior, V.; Calefi, A.S.; Fukushima, A.R.; Spinosa, H.S.; Maiorka, P.C. Poisoning of cats and dogs by the carbamate pesticides aldicarb and carbofuran. Research in Veterinary Science, 102: 142-149, 2015.

Fracassi, F.; Tamborini, A. Reversible megaoesophagus associated with primary hypothyroidism in a dog. Veterinary Record, 168(12): 329b, 2011.

Hopper, K.; Beck, C.; Slocombe, R.F. Megaoesophagus in adult dogs secondary to Australian tiger snake envenomation. Australian Veterinary Journal, 79(10): 672675, 2001

Jokanovic, M.; Kosanovic, M.; Brkic, D.; Vukomanovic, P. Organophosphate induced delayed polyneuropathy in man: an overview. Clinical Neurology and Neurosurgery, 113(1): 7-10, 2011.

Kanemoto, Y.; Fukushima, K.; Kanemoto, H.; Ohno, K.; Tsujimoto, H. Long-term management of a dog with idiopathic megaesophagus and recurrent aspiration pneumonia by use of an indwelling esophagostomy tube for suction of esophageal content and esophagogastric tube feeding. Journal of Veterinary Medical Science, 79(1): 188-191, 2017.

King, A.M.; Aaron, C.K. Organophosphate and carbamate poisoning. Emergency Medicine Clinics of North America, 33(1): 133-151, 2015.

Lotti, M.; Moretto, A. Do carbamates cause polyneuropathy? Muscle \& Nerve, 34(4): 499$502,2006$.

Mace, S.; Shelton, G.D.; Eddlestone, S. Megaesophagus in the $\operatorname{dog}$ and cat. Tierarztliche Praxis Ausgabe K Kleintiere Heimtiere, 41(2): 123-131, 2013.

Manning, K.; Birkenheuer, A.J.; Briley, J.; Montgomery, S.A.; Harris, J.; Vanone, S.L.; Gookin, J.L. Intermittent at-home suctioning of esophageal content for prevention of recurrent aspirative pneumonia in four dogs with megaesophagus. Journal of Veterinary Internal Medicine, 30(5): 1715-1719, 2016.

Ruiz-Suárez, N.; Boada, L.D.; HenríqueHernández, L.A.; González-Moreo, S.; SuárezPérez, A.; Camacho, M.; Zumbado, M.; Almeida-González, M.; Del Mar Travieso-Aja, M.; Luzardo, O.P. Continued implication of the banned pesticides carbofuran and aldicarb 
in the poisoning of domestic and wild animal of the Canary Islands (Spain). The Science of Total Environment, 505: 1093-1099, 2015.

Tennakoon, S.; Perera, B.; Haturusinghe, L. Intentional poisoning cases of animals with acetilcholinesterase pesticide-carbofuran in Sri
Lanka. Legal Medicine (Tokyo, Japan), Suppl 1: S500-S502, 2009.

Tinson, E.; Boller, E.; Davis, M. A suspected case of intermediate syndrome in a dog with carbamate toxicosis. Australian Veterinary Journal, 95(6): 201-206, 2017. 